\title{
An Analysis of Key Aspects of the Illiterate Ecuadorian Population Aged 15 Years and Older
}

\author{
Efstathios Stefos ${ }^{1}$, Diego P. Ortega ${ }^{1} \&$ Gina Valdivieso ${ }^{2}$ \\ ${ }^{1}$ Universidad Nacional de Educación UNAE, Azogues, Ecuador \\ ${ }^{2}$ Facultad de Psicología, Pontificia Universidad Católica del Ecuador (PUCE), Quito, Ecuador \\ Correspondence: Efstathios Stefos, Universidad Nacional de Educación (UNAE), Azogues, Cañar, Parroquia \\ Javier Loyola (sector Chuquipata), Ecuador. Tel: 593-7-370-1200. E-mail: estefos@aegean.gr
}

Received: June 1, 2017

Accepted: June 7, 2017

Online Published: July 2, 2017

doi:10.5539/res.v9n3p89

URL: http://doi.org/10.5539/res.v9n3p89

\begin{abstract}
This article aims to provide an analysis of several aspects that comprise the profile of the Ecuadorian population aged 15 years old and over who do not know how to read and write. The approach, employed in this research study, focuses on a descriptive analysis and a multidimensional statistical analysis. Available data from the National Survey of Employment, Unemployment and Underemployment of Ecuador (ENEMDU), conducted by the National Institute of Statistics and Censuses (INEC) in 2016, was utilized as the main source of information in the study. One of the previous surveys, conducted in the country in 2006, suggested that the equivalent percentage of the illiterate population was $8.63 \%$; therefore, these data indicate that the population under examination has decreased considerably in the last ten years. This means that a highly important enhancement in terms of literacy has occurred over this period of time in Ecuador. The study results, drawn from the descriptive analysis and the hierarchical analysis carried out as part of this research, may be key at the moment of creating policies, educational campaings and nationwide, special programs focused on helping reduce and eliminate illiteracy across the nation in the upcoming years.
\end{abstract}

Keywords: illiteracy, decrease, Ecuador, statistical analysis

\section{Introduction}

The objective of this study is to analyze different aspects (e.g., langauges spoken, school attendance, level of instruction, use of computer and the Internet, occupational fields, just to mention a few) that make up the profile of the $5.65 \%$ of the Ecuadorian population aged fifteen years old and over (660916 people), who do not know how to read and write (INEC, 2016). In the year 2006 the equivalent percentage was $8.63 \%$ (798094 people), which means that during the last ten years there has been a decrease of $17.19 \%$ of the population who does not how to read and write (INEC, 2006). Although, a significant improvement was shown between 2006 and 2016, there is still an important challenge to overcome, since 660916 Ecuadorians are still illiterate.

According to UNESCO, it is considered a literate person who can read, write, and comprehend a basic and short text about daily life. Adult illiteracy is defined by the percentage of the population aged fifteen years old and over, who are not able to read, write and comprehend a basic and short text about daily life (UNESCO, 2009). This study is focused on a statistical analysis that employs available data (Ponce \& Onofa, 2009), and its results may help design policies, campaigns, and special programs aimed at reducing the illiteracy rate in Ecuador (SENPLADES, 2013).

\section{Materials and Methods}

The study was based on the data from the 2016 National Survey of Employment, Unemployment, and Underemployment of Ecuador (ENEMDU) carried out by the National Institute of Statistics and Censuses (INEC), using a multiplier that was applied to each individual in the sample with the aim of expanding the sample to the population; this procedure was used in the present study to estimate the total population (INEC, 2016).

Within the framework of the study, a descriptive analysis and a multidimensional statistical analysis were carried out. The descriptive analysis shows the frequencies and the percentages of the variables that were explored by this study (Sarmiento et al., 2016). The multidimensional statistical analysis was utilized with the aim of 
showing a classification in different clusters. The method used was the hierarchical clustering that defines the clusters of people based on their answers and common characteristics. This method also presents a classification figure that links these clusters (Valdivieso et al., 2017; Stefos, 2015).

The software R and the software SPAD v.4.5 were employed for the data analysis; the latter was offered by the Faculty of Humanities of the University of the Aegean (Stefos \& Koulianidi, 2016).

\section{The Descriptive Analysis}

$42.16 \%$ of Ecuadorian population aged 15 years old and over, who do not know how to read and write, live in urban areas, while $57.84 \%$ live in rural areas (Table 1).

Table 1. Area of residence

\begin{tabular}{ccc}
\hline & $\mathrm{n}$ & $\%$ \\
\cline { 2 - 3 } Urban & 278630 & $42.16 \%$ \\
Rural & 382286 & $57.84 \%$ \\
Total & 660916 & $100.00 \%$ \\
\hline
\end{tabular}

$39.19 \%$ of the population aged 15 years old and over are men and $60.81 \%$ of the population is women (Table 2 ).

Table 2. Gender

\begin{tabular}{ccc}
\hline & $\mathrm{n}$ & $\%$ \\
\cline { 2 - 3 } Men & 259021 & $39.19 \%$ \\
Women & 401896 & $60.81 \%$ \\
Total & 660916 & $100.00 \%$ \\
\hline
\end{tabular}

$4.30 \%$ of the population is between 15 and 24 years old, $7.69 \%$ are between 25 and 34 years old, $10.11 \%$ are between 35 and 44 years old, $14.33 \%$ are between 45 and 54 years old, $19.01 \%$ are between 55 and 64 years old, $21.15 \%$ are between 65 and 74 years old, $15.79 \%$ are between 75 and 84 years old, $7.27 \%$ are between 85 and 97 years old, and $0.34 \%$ are 98 years old and over (Table 3 ).

Table 3. Age

\begin{tabular}{ccc}
\hline & $\mathrm{n}$ & $\%$ \\
\cline { 2 - 3 } $15-24$ & 28438 & $4.30 \%$ \\
$25-34$ & 50823 & $7.69 \%$ \\
$35-44$ & 66791 & $10.11 \%$ \\
$45-54$ & 94716 & $14.33 \%$ \\
$55-64$ & 125618 & $19.01 \%$ \\
$65-74$ & 139753 & $21.15 \%$ \\
$75-84$ & 104371 & $15.79 \%$ \\
$85-97$ & 48055 & $7.27 \%$ \\
98 \& over & 2234 & $0.34 \%$ \\
N/A & 119 & $0.02 \%$ \\
Total & 660916 & $100.00 \%$ \\
\hline
\end{tabular}


$34.61 \%$ of the population aged 15 years old and over are married, $7.94 \%$ of the population is separated, $1.59 \%$ are divorced, $19.29 \%$ are widowed, $20.78 \%$ are in a common law relationship, and $15.80 \%$ are single (Table 4 ).

Table 4. Marital status

\begin{tabular}{lcc}
\hline & $\mathrm{n}$ & $\%$ \\
\cline { 2 - 3 } Married & 228742 & $34.61 \%$ \\
Separated & 52465 & $7.94 \%$ \\
Divorced & 10487 & $1.59 \%$ \\
Widowed & 127502 & $19.29 \%$ \\
Common law relationship & 137309 & $20.78 \%$ \\
Single & 104411 & $15.80 \%$ \\
Total & 660916 & $100.00 \%$ \\
\hline
\end{tabular}

$0.75 \%$ of the population aged 15 years old and over attended school, while $99.25 \%$ of the population did not attend school (Table 5).

Table 5. School attendance

\begin{tabular}{ccc}
\hline & $\mathrm{n}$ & $\%$ \\
\cline { 2 - 3 } Yes & 4975 & $0.75 \%$ \\
No & 655941 & $99.25 \%$ \\
Total & 660916 & $100.00 \%$ \\
\hline
\end{tabular}

$39.79 \%$ of the population aged 15 years old and over did not attend school because of their age; $0.38 \%$ of the population, due to completion of studies; $15.00 \%$, due to lack of economic resources; $0.63 \%$, as a result of school failure; $17.57 \%$, because of job responsibilities; $9.47 \%$, due to health and disability issues; $4.79 \%$, as a result of assisting in household chores; $0.92 \%$, because their families did not allow them to study; $0.63 \%$, due to lack of educational institutions; $8.64 \%$, as a result of a lack of interest in studying; $0.01 \%$, because of pregnancy; $0.02 \%$, due to space availability at school; $0.01 \%$, because of fear of peer intimidation; $1.17 \%$, as a result of looking after children; and $0.22 \%$, due to other reasons (Table 6).

Table 6. Reasons for truancy

\begin{tabular}{lcc}
\hline & $\mathrm{n}$ & $\%$ \\
\cline { 2 - 3 } Age & 262979 & $39.79 \%$ \\
Completion of studies & 2492 & $0.38 \%$ \\
Lack of economic resources & 99107 & $15.00 \%$ \\
School failure & 4167 & $0.63 \%$ \\
Job responsibilities & 116136 & $17.57 \%$ \\
Health and disability issues & 62562 & $9.47 \%$ \\
Assisting in household chores & 31681 & $4.79 \%$ \\
Family did not allow them to study & 6098 & $0.92 \%$ \\
Lack of educational institutions & 4146 & $0.63 \%$ \\
Lack of interest in studying & 57134 & $8.64 \%$ \\
Pregnancy & 70 & $0.01 \%$ \\
Space availability at school & 127 & $0.02 \%$ \\
\hline
\end{tabular}




\begin{tabular}{lcc}
\hline Fear of peer intimidation & 94 & $0.01 \%$ \\
Looking after children & 7723 & $1.17 \%$ \\
Other & 1426 & $0.22 \%$ \\
N/A & 4975 & $0.75 \%$ \\
Total & 660916 & $100.00 \%$ \\
\hline
\end{tabular}

$68.84 \%$ of the population aged 15 years old and over have no level of schooling. With regard to the instruction level of the rest of the population, $3.18 \%$ attended literacy center, $26.96 \%$ attended primary school, and $1.02 \%$ attended basic education (Table 7).

Table 7. Level of instruction

\begin{tabular}{lcc}
\hline & $\mathrm{n}$ & $\%$ \\
\cline { 2 - 3 } None & 454985 & $68.84 \%$ \\
Literacy center & 20987 & $3.18 \%$ \\
Primary school & 178173 & $26.96 \%$ \\
Basic education & 6771 & $1.02 \%$ \\
Total & 660916 & $100.00 \%$ \\
\hline
\end{tabular}

$0.81 \%$ of the population aged 15 years old and over attended school less than one year, $14.35 \%$ of the population attended school for one year, $14.77 \%$ attended school for two years, $0.65 \%$ attended school for three years, $0.36 \%$ attended school for four years, $0.002 \%$ attended school for five years, $0.21 \%$ attended school for 6 years, and $0.01 \%$ attended school for ten years (Table 8 ).

Table 8. Number of school years passed

\begin{tabular}{lcc}
\hline & $\mathrm{n}$ & $\%$ \\
\cline { 2 - 3 } Less than one year & 5331 & $0.81 \%$ \\
1 year & 94816 & $14.35 \%$ \\
2 years & 97619 & $14.77 \%$ \\
3 years & 4310 & $0.65 \%$ \\
4 years & 2404 & $0.36 \%$ \\
5 years & 14 & $0.002 \%$ \\
6 years & 1392 & $0.21 \%$ \\
10 years & 45 & $0.01 \%$ \\
N/A & 454985 & $68.84 \%$ \\
Total & 660916 & $100.00 \%$ \\
\hline
\end{tabular}

$1.60 \%$ of the population aged 15 years old and over speak indigenous language only, $18.38 \%$ of the population speaks indigenous language and the Spanish language, $77.81 \%$ speak Spanish only, $0.13 \%$ speak Spanish and a foreign language, $0.07 \%$ speak indigenous language and a foreign language, $0.12 \%$ speak a foreign language only, and $1.90 \%$ do not speak (Table 9). 
Table 9. Languages spoken

\begin{tabular}{lcc}
\hline & $\mathrm{n}$ & $\%$ \\
\cline { 2 - 3 } Indigenous language only & 10549 & $1.60 \%$ \\
Indigenous language and Spanish & 121503 & $18.38 \%$ \\
Spanish only & 514239 & $77.81 \%$ \\
Spanish and foreign language & 850 & $0.13 \%$ \\
Indigenous language and a foreign language & 451 & $0.07 \%$ \\
Foreign language & 789 & $0.12 \%$ \\
Do not speak & 12536 & $1.90 \%$ \\
Total & 660916 & $100.00 \%$ \\
\hline
\end{tabular}

$21.63 \%$ of the population aged 15 years old and over are indigenous, $1.03 \%$ of the population is afro-Ecuadorians, $2.26 \%$ are blacks, $1.67 \%$ are mulattos, $9.00 \%$ are montubios, $63.07 \%$ are mestizos, and $1.25 \%$ are whites (Table 10).

Table 10. Ethnic self-identification

\begin{tabular}{lcc}
\hline & $\mathrm{n}$ & $\%$ \\
\cline { 2 - 3 } Indigenious & 142950 & $21.63 \%$ \\
Afro-ecuadorian & 6798 & $1.03 \%$ \\
Black & 14904 & $2.26 \%$ \\
Mulatto & 11066 & $1.67 \%$ \\
Montubio & 59498 & $9.00 \%$ \\
Mestizo & 416815 & $63.07 \%$ \\
White & 8293 & $1.25 \%$ \\
Other & 592 & $0.09 \%$ \\
Total & 660916 & $100.00 \%$ \\
\hline
\end{tabular}

$1.19 \%$ of the population aged 15 years old and over are landlords, $2.51 \%$ of the population is retired, $0.28 \%$ are students, $18.96 \%$ are housewives, and $19.47 \%$ are disabled (Table 11 ).

Table 11. Type of unemployment

\begin{tabular}{lcc}
\hline & $\mathrm{n}$ & $\%$ \\
\cline { 2 - 3 } Landlord & 7836 & $1.19 \%$ \\
Retired & 16586 & $2.51 \%$ \\
Student & 1869 & $0.28 \%$ \\
Housewife & 125340 & $18.96 \%$ \\
Disabled & 128676 & $19.47 \%$ \\
Other & 8211 & $1.24 \%$ \\
N/A & 372400 & $56.35 \%$ \\
Total & 660916 & $100.00 \%$ \\
\hline
\end{tabular}


$32.00 \%$ of the population aged 15 years old and over have an active cell phone, while $61.82 \%$ have no cell phone (Table 12).

Table 12. Possessing an active cell phone

\begin{tabular}{ccc}
\hline & $\mathrm{n}$ & $\%$ \\
\cline { 2 - 3 } Yes & 211514 & $32.00 \%$ \\
No & 408580 & $61.82 \%$ \\
N/A & 40823 & $6.18 \%$ \\
Total & 660916 & $100.00 \%$ \\
\hline
\end{tabular}

$1.54 \%$ of the population aged 15 years old and over have a smartphone, while $30.64 \%$ have no smartphone (Table 13).

Table 13. Cell phone type-smartphone

\begin{tabular}{ccc}
\hline & $\mathrm{n}$ & $\%$ \\
\cline { 2 - 3 } Yes & 10190 & $1.54 \%$ \\
No & 201323 & $30.46 \%$ \\
N/A & 449403 & $68.00 \%$ \\
Total & 660916 & $100.00 \%$ \\
\hline
\end{tabular}

$1.12 \%$ of the population aged 15 years old and over have used a computer during the last 12 months, while $92.70 \%$ of the population has not used a computer during the last 12 months (Table 14).

Table 14. Use of computer during the last 12 months

\begin{tabular}{ccc}
\hline & $\mathrm{n}$ & $\%$ \\
\cline { 2 - 3 } Yes & 7407 & $1.12 \%$ \\
No & 612686 & $92.70 \%$ \\
N/A & 40823 & $6.18 \%$ \\
Total & 660916 & $100.00 \%$ \\
\hline
\end{tabular}

$1.28 \%$ of the population aged 15 years old and over have used the Internet during the last 12 months, while $92.54 \%$ of the population has not used the Internet during the last 12 months (Table 15).

Table 15. Use of the Internet during the last 12 months

\begin{tabular}{ccc}
\hline & $\mathrm{n}$ & $\%$ \\
\cline { 2 - 3 } Yes & 8475 & $1.28 \%$ \\
No & 611619 & $92.54 \%$ \\
N/A & 40823 & $6.18 \%$ \\
Total & 660916 & $100.00 \%$ \\
\hline
\end{tabular}

$47.51 \%$ of the population aged 15 years old and over live in the highlands, $48.38 \%$ of the population lives in the pacific coast region, and $4.11 \%$ live in the amazon region (Table 16 ). 
Table 16. Natural region

\begin{tabular}{lcc}
\hline & $\mathrm{n}$ & $\%$ \\
\cline { 2 - 3 } Highlands & 314021 & $47.51 \%$ \\
Pacific coast & 319761 & $48.38 \%$ \\
Amazon & 27134 & $4.11 \%$ \\
Total & 660916 & $100.00 \%$ \\
\hline
\end{tabular}

$36.18 \%$ of the population aged 15 years old and over work in agriculture, ranching, hunting, forestry, and fishing; $0.13 \%$ of the population works in mining and quarry; $2.85 \%$ work in manufacture industries; $0.02 \%$, in electricity, gas, and air conditioning supplies; $0.06 \%$, in water and sewage system distribution; $2.46 \%$, in construction industry; $5.41 \%$, in trade business and automobile reparation; $1.13 \%$, in transportation and storage; $2.40 \%$, in lodging and food services; $0.02 \%$, in professional, scientific and technical activities; $0.73 \%$, in administrative and support services; $0.31 \%$, in public administration, defense, and social security; $0.06 \%$, in teaching; $0.05 \%$, in health and social services; $0.21 \%$, in arts, entertainment, and recreation; $1.76 \%$, in service activities; and $1.23 \%$, in domestic service at private homes (Table 17).

Table 17. Occupational fields

\begin{tabular}{lcc}
\hline & $\mathrm{n}$ & $\%$ \\
\cline { 2 - 3 } Agriculture, ranching, hunting, forestry, and fishing & 239130 & $36.18 \%$ \\
Mining and quarry & 842 & $0.13 \%$ \\
Manufacture industries & 18836 & $2.85 \%$ \\
Electricity, gas, and air conditioning supplies & 135 & $0.02 \%$ \\
Water and sewage system distribution & 413 & $0.06 \%$ \\
Construction industry & 16284 & $2.46 \%$ \\
Trade business and automobile reparation & 35737 & $5.41 \%$ \\
Transportation and storage & 7457 & $1.13 \%$ \\
Lodging and food services & 15877 & $2.40 \%$ \\
Professional, scientific, and technical activities & 113 & $0.02 \%$ \\
Administrative and support services & 4809 & $0.73 \%$ \\
Public administration, defense, and social security & 2075 & $0.31 \%$ \\
Teaching & 378 & $0.06 \%$ \\
Health and social services & 357 & $0.05 \%$ \\
Arts, entertainment, and recreation & 1404 & $0.21 \%$ \\
Service activities & 11603 & $1.76 \%$ \\
Domestic service at private homes & 8098 & $1.23 \%$ \\
N/A & 297368 & $44.99 \%$ \\
Total & 660916 & $100.00 \%$ \\
\hline
\end{tabular}

$62.87 \%$ of the population aged 15 years old and over do not consider themselves to be poor based on their income, while $36.52 \%$ of the population considers themselves as poor (Table 18). 
Table 18. Poverty based on income

\begin{tabular}{ccc}
\hline & $\mathrm{n}$ & $\%$ \\
\cline { 2 - 3 } Non-poor & 415503 & $62.87 \%$ \\
Poor & 241424 & $36.53 \%$ \\
N/A & 3990 & $0.60 \%$ \\
Total & 660916 & $100.00 \%$ \\
\hline
\end{tabular}

$85.96 \%$ of the population aged 15 years old and over do not consider themselves to be indigent based on their income, while $13.43 \%$ of the population considers themselves as indigent (Table 19).

Table 19. Extreme poverty based on income

\begin{tabular}{lcc}
\hline & $\mathrm{n}$ & $\%$ \\
\cline { 2 - 3 } Non-indigent & 568141 & $85.96 \%$ \\
Indigent & 88786 & $13.43 \%$ \\
N/A & 3990 & $0.60 \%$ \\
Total & 660916 & $100.00 \%$ \\
\hline
\end{tabular}

$7.19 \%$ of the population aged 15 years old and over have suitable employment, $8.21 \%$ of the population is underemployed because of insufficiency of time, $2.03 \%$ are underemployed due to low income, $27.84 \%$ have other unsuitable job; $9.73 \%$ have unpaid jobs; $0.99 \%$ are open unemployed; $0.35 \%$ are hidden unemployed, and $43.65 \%$ are economically inactive (Table 20 ).

Table 20. Status of employment

\begin{tabular}{lcc}
\hline & $\mathrm{n}$ & $\%$ \\
\cline { 2 - 3 } Suitable employment & 47550 & $7.19 \%$ \\
Underemployment because of insufficiency of time & 54255 & $8.21 \%$ \\
Underemployment due to low income & 13396 & $2.03 \%$ \\
Other unsuitable job & 184027 & $27.84 \%$ \\
Unpaid job & 64320 & $9.73 \%$ \\
Open unemployment & 6513 & $0.99 \%$ \\
Hidden unemployment & 2338 & $0.35 \%$ \\
Economically inactive & 288516 & $43.65 \%$ \\
Total & 660916 & $100.00 \%$ \\
\hline
\end{tabular}

\section{Hierarchical Analysis}

The hierarchical clustering led to the formation of six clusters, which are graphically represented in the figure below (Papapostolou \& Stefos, 2013). 


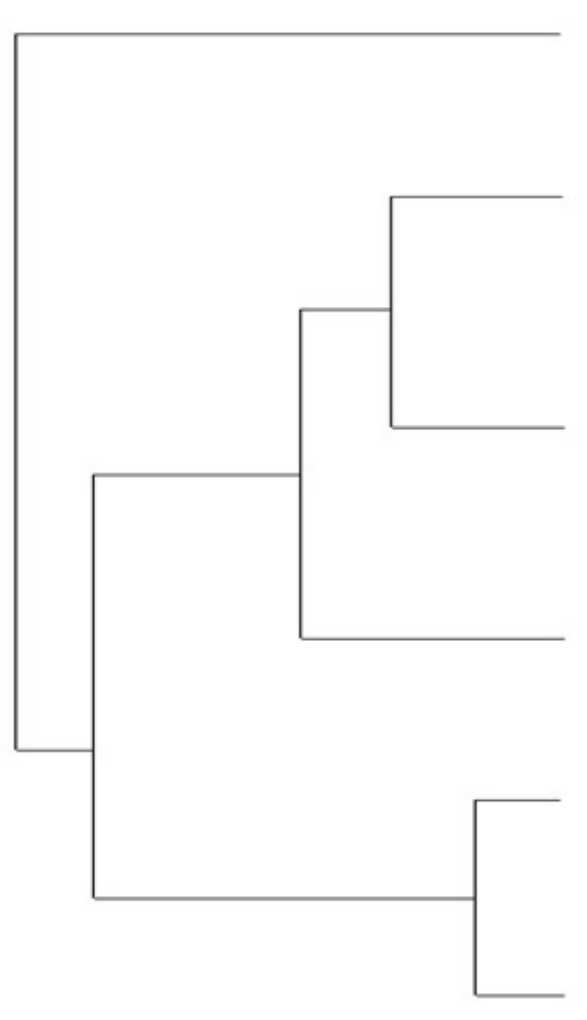

Sixth cluster, $5.39 \%$ of the population

Fifth cluster, $31.62 \%$ of the population

Fourth cluster, $18.75 \%$ of the population

Third cluster, $12.87 \%$ of the population

Second cluster, $25.33 \%$ of the population

First cluster, $6.04 \%$ of the population

Figure 1. Hierarchical analysis

First cluster, $6.04 \%$ of the population

Persons from the first cluster declared they do not attend school because of health and disability issues, and they are single, disabled and economically inactive.

Second cluster, $25.33 \%$ of the population

Persons from the second cluster are economically inactive, housewives, and they declared they do not attend school because of their age.

Third cluster, $12.87 \%$ of the population

Persons from this cluster consider themselves as indigenous, live in rural areas and in the Amazon region, speak indigenous language only, are poor, and work in agriculture and ranching.

Fourth cluster, $18.75 \%$ of the population

Persons from the fourth cluster live in the pacific coast region, are in a common law relationship, speak Spanish only, and have an active cell phone.

Fifth cluster, $31.62 \%$ of the population

The fifth cluster is made up of persons who responded they live in the highlands, work in culture and ranching, and speak Spanish and indigenous language.

Sixth cluster, $5.39 \%$ of the population

Persons from the sixth cluster responded that they are single, disabled, economically inactive, and live in the urban area.

The differences of the aforementioned clusters are shown in Figure 2, where the graphic of Correspondence Analysis (factorial level 1x2) presents the centroids of the six clusters in both axes (Stefos \& Papapostolou, 2013). In addition, it defines the differences and the similarities among the persons of the six clusters. 


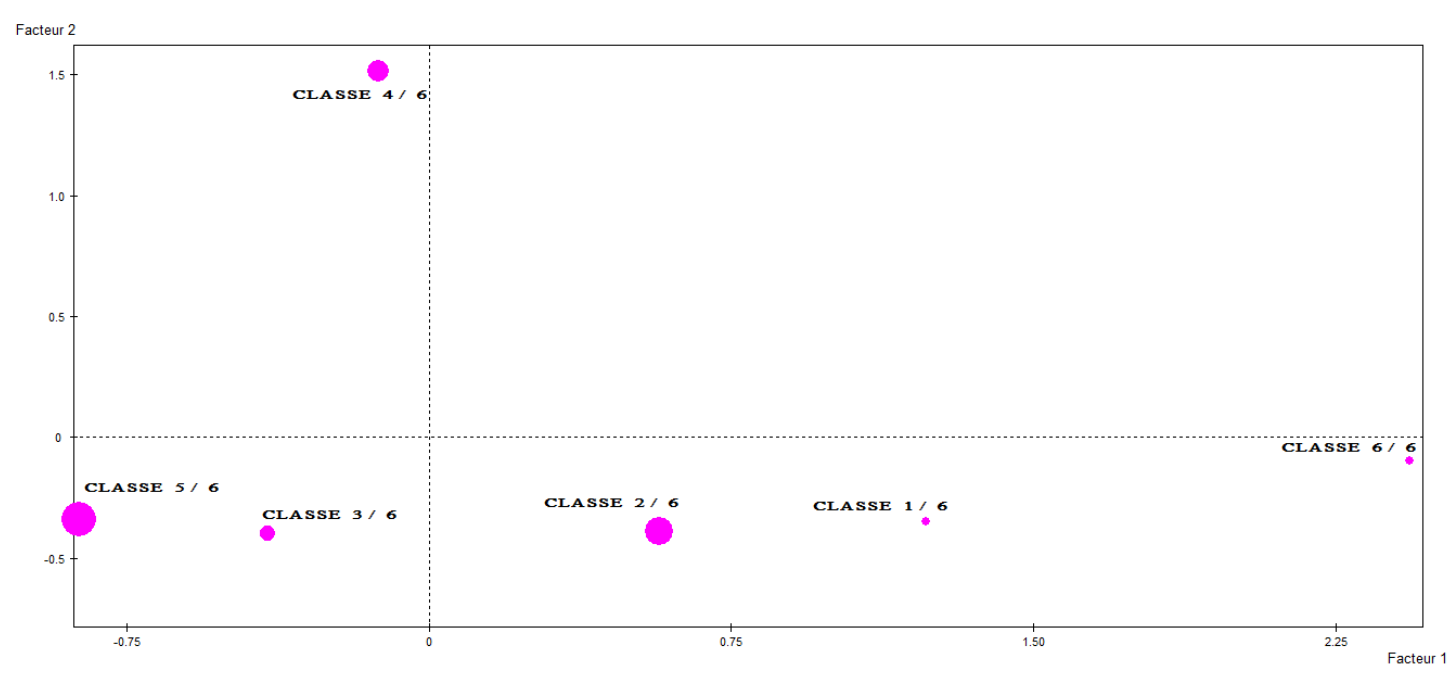

Figure 2. Correspondence analysis

\section{Conclusions}

The objective of this study was the analysis of the social profile of the Ecuadorian population aged 15 years old and over, who do not know how to read and write. Within the framework of the study, a multidimensional statistical analysis was carried out, which confirmed the results of the descriptive analysis (Papapostolou et al., 2013; Stefos et al., 2011).

The majority of Ecuadorians aged 14 years old and over who do not know how to read and write are women (60.81\%). $63.56 \%$ of the population is over 54 years old, $34.61 \%$ are married and $20.78 \%$ are in a common law relationship. Only $0.75 \%$ of the population attends school, $39.79 \%$ do not go to school because of their age; $17.57 \%$, due to job responsibilities; $15.00 \%$, due to lack of economic resources; and $9.47 \%$, due to health and disability issues. Additionally, the information shows that $14.35 \%$ of the population went to school for one year and $14.77 \%$ went to school for 2 years. $63.07 \%$ of the population is mestizos, $21.63 \%$ are indigenous, $9.00 \%$ are montubios, $19.47 \%$ are disabled, and $18.96 \%$ are housewives. In addition, it was found that $32.00 \%$ have an active cell phone, $1.54 \%$ have a smartphone, $1.12 \%$ have used a computer during the last 12 months, and $1.28 \%$ have used the Internet. The information also indicates that $36.18 \%$ of the population works in agriculture, ranching, hunting, forestry, and fishing, and $5.41 \%$ work in trade business and automobile reparation. $36.53 \%$ of the population considers themselves as poor and $13.43 \%$ as indigent (Castellano et al., 2017).

\section{Acknowledgments}

We would like to express our deepest gratitude to the Faculty of Humanities of the University of the Aegean for donating the statistical software SPAD v.4.5 used in this study.

\section{References}

Castellano, J. M., Stefos, E., \& Williams Goodrich, L. G. (2017). The Educational and Social Profile of the Indigenous People of Ecuador: A Multidimensional Analysis. Review of European Studies, 9(1), 137-147. https://doi.org/10.5539/res.v9n1p137

Instituto Nacional de Estadística y Censos-INEC. (2006). Encuesta Nacional de Empleo, Desempleo y Subempleo-ENEMDU. Quito.

Instituto Nacional de Estadística y Censos-INEC. (2016). Encuesta Nacional de Empleo, Desempleo y Subempleo-ENEMDU. Quito.

Papapostolou, I., \& Stefos, E. (2013). Qualitative analysis on pedagogical research. Methodological approaches. In I. Papapostolou (Ed.), Educational activities. Teaching Interventions in Secondary Education (pp. 244-251). Rhodes: Evdimos Editions.

Papapostolou, I., Papapostoulou, K., \& Stefos, E. (2013). Educational Research. In From Qualitative to Quantitative analysis (p. 178). Rhodes: Evdimos Editions. 
Ponce, J., \& Onofa, M. (2009). Alfabetización en el Ecuador: Evolución histórica, información actualizada y mapa nacional del analfabetismo, 2009. Quito: UNESCO y Ministerio de Educación del Ecuador.

Sarmiento Sarmiento, N. M., Paredes Proaño, A. M., \& Stefos, E. (2016). Deaths by Suicide in Ecuador: A Quantitative Data Analysis. Review of European Studies, 8(1), 145-156. https://doi.org/10.5539/res.v8n1p145

Secretaria Nacional de Planificación y Desarrollo-SENPLADES. (2013). Plan Nacional de Desarrollo/Plan Nacional para el Buen Vivir 2013-2017. Quito.

Stefos, E. (2015). Causes of Death of Indigenous Ecuadorians. International Journal of Clinical Medicine Research, 2(6), 65-70.

Stefos, E., \& Efstathiou, I. (2013). Quantitative analysis of the data of the School of Trianta during the period of 1906-1916. In I. Papapostolou (Ed.), Educational activities. Teaching Interventions in Secondary Education (pp. 29-57). Rhodes: Evdimos Editions.

Stefos, E., \& Koulianidi, G. (2016). Nutrition Data Analysis Using R: Applications in Higher Education. Health Sciences Research, 3(1), 10-16.

Stefos, E., \& Papapostolou, I. (2013). Research Methodology. In Processes and suggestions (p. 406). Rhodes: Evdimos Editions.

Stefos, E., Athanasiadis, I., Gialamas, B., \& Tsolakidis, C. (2011). The Use of New Technologies and the Project Method in Teaching Statistics: A Case Study in Higher Education. HMS i JME, 3, 84-100.

Valdivieso, G., Stefos, E., \& Lalama, R. (2017). The Ecuadorian Amazon: A Data Analysis of Social and Educational Characteristics of the Population. Review of European Studies, 9(1), 120-129. https://doi.org/10.5539/res.v9n1p120

\section{Copyrights}

Copyright for this article is retained by the author(s), with first publication rights granted to the journal.

This is an open-access article distributed under the terms and conditions of the Creative Commons Attribution license (http://creativecommons.org/licenses/by/4.0/). 